\begin{tabular}{ll|l} 
Case Reports in & \multicolumn{2}{c}{ Case Rep Gastroenterol 2013;7:492-497 } \\
\cline { 2 - 3 } Gastroenterology & $\begin{array}{l}\text { DOI: 10.1159/000357302 } \\
\text { Published online: November 28, 2013 }\end{array}$ & $\begin{array}{l}\text { ○ 2013 S. Karger AG, Basel } \\
\text { www.karger.com/crg }\end{array}$ \\
\hline & $\begin{array}{l}\text { This is an Open Access article licensed under the terms of the Creative Commons } \\
\text { Attribution-NonCommercial 3.0 Unported license (CC BY-NC) (www.karger.com/OA- } \\
\text { license), applicable to the online version of the article only. Distribution permitted for non- } \\
\text { commercial purposes only. }\end{array}$
\end{tabular}

\title{
Small Bowel Metastasis of Hepatocellular Carcinoma Detected by Capsule Endoscopy
}

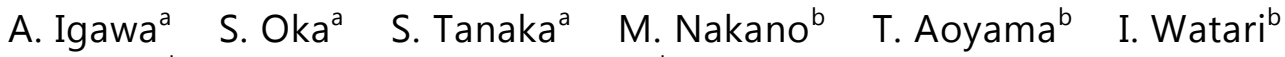 \\ H. Aikata ${ }^{b}$ K. Arihiro ${ }^{c} \quad$ K. Chayamab \\ Departments of ${ }^{a}$ Endoscopy, ${ }^{b}$ Gastroenterology and Metabolism, and ${ }^{c}$ Pathology, \\ Hiroshima University Hospital, Hiroshima, Japan
}

\section{Key Words}

Hepatocellular carcinoma - Small bowel metastasis · Capsule endoscopy · Double-balloon endoscopy

\begin{abstract}
We report a rare case of metastasis of hepatocellular carcinoma (HCC) to the small bowel that presented as a pedunculated epithelial polyp. A 60-year-old man with liver cirrhosis type $B$ was treated for HCC (stage IVb) at our hospital. He had been admitted for melena and anemia. Capsule endoscopy was performed in this patient with obscure gastrointestinal bleeding. It showed a polypoid lesion with bleeding in the ileum. Double-balloon endoscopy was performed. The lesion was determined to be a pedunculated polyp in the ileum. Histological examination of biopsy specimens showed tumor cells resembling HCC. We performed endoscopic mucosal resection for the lesion by double-balloon endoscopy to prevent bleeding from the tumor. The patient had no melena or anemia and his condition improved after endoscopic mucosal resection. However, he died of liver failure 2 months later.

(c) 2013 S. Karger AG, Basel
\end{abstract}

\section{Introduction}

Hepatocellular carcinoma (HCC) is one of the most common malignancies worldwide, and its incidence has been increasing in recent years. HCC is a so highly invasive tumor that metastasizes hematogenously and through lymphatics to distant sites. The most common site of HCC metastasis is reported to be the lung (46.3\%), followed by the regional lymph nodes $(30.3 \%)$, adrenal glands (12.5\%) and bone (11.2\%) [1]. Metastasis of HCC to the

Shiro Oka

Hiroshima University Hospital

1-2-3 Kasumi Minami-ku

Hiroshima 7348551 (Japan)

E-Mailoka4683@hiroshima-u.ac.jp 
Igawa et al.: Small Bowel Metastasis of Hepatocellular Carcinoma Detected by Capsule Endoscopy

gastrointestinal tract is rare and found in only $2 \%$ of cases [2]. Moreover, no cases of small bowel metastasis of HCC have detected by capsule endoscopy (CE). Here, we report a case of small bowel metastasis of HCC detected by CE and double-balloon endoscopy (DBE) as a pedunculated epithelial polyp.

\section{Case Report}

A 60-year-old man with liver cirrhosis type B was treated with sorafenib chemotherapy for HCC (stage IVb) at Hiroshima University Hospital. He had been admitted for melena and anemia since October 2011. There was no obvious source of bleeding by both upper and lower gastrointestinal endoscopy. Therefore, CE was performed in November 2011. Physical findings were normal. Laboratory examination indicated a white blood cell count of $3,850 / \mu \mathrm{l}$, a red blood cell count of $325 \times 10^{4} / \mu \mathrm{l}$ and a platelet count of $11.0 \times 10^{4} / \mu$ l. The hemoglobin concentration was $9.2 \mathrm{~g} / \mathrm{dl}$. Liver function examination revealed the following levels: aspartate aminotransferase $61 \mathrm{IU} / \mathrm{l}$ (normal 2-39 IU/l), alanine aminotransferase 57 IU/l (normal 2-39 IU/l), total protein $7.7 \mathrm{~g} / \mathrm{dl}$ (normal 6.5-8.1 g/dl), serum albumin $3.1 \mathrm{~g} / \mathrm{dl}$ (normal 3.8-5.2 g/dl), alkaline phosphatase $722 \mathrm{IU} / \mathrm{l}$ (normal 96-310 IU/l), leucine aminopeptidase $177 \mathrm{IU} / \mathrm{l}$ (normal 45-71 IU/l), $\gamma$-glutamyl transpeptidase $138 \mathrm{IU} / \mathrm{l}$, cholinesterase $0.10 \mathrm{IU} / \mathrm{l}$ (normal 0.6-1.2 IU/l), and total bilirubin $1.4 \mathrm{mg} / \mathrm{dl}$ (normal 0.1-0.4 $\mathrm{mg} / \mathrm{dl}$ ). With respect to renal function, the blood urea nitrogen level was $43.6 \mathrm{mg} / \mathrm{dl}$ and the creatinine level $2.54 \mathrm{mg} / \mathrm{dl}$. The results for tumor markers were negative for carbohydrate antigen 19-9 and carcinoembryonic antigen; however, the levels of alpha fetoprotein and protein indicated by vitamin $\mathrm{K}$ absence (PIVKA II) were high at $86.5 \mathrm{ng} / \mathrm{ml}$ (normal $\leq 5$ $\mathrm{ng} / \mathrm{ml}$ ) and 45,302 $\mathrm{ng} / \mathrm{ml}$ (normal $\leq 10 \mathrm{ng} / \mathrm{ml}$ ), respectively. The Child-Pugh score was 6 points (grade B).

A computed tomography (CT) scan showed that the HCC consisted of a tumor in the liver (fig. 1a), a portal vein tumor thrombus (VP2) (fig. 1b) and multiple lung metastases (fig. 1c). CE showed a polypoid lesion with bleeding in the ileum, but there were no other findings in the small bowel (fig. 2a). DBE was performed after CE. The lesion was determined to be a pedunculated polyp in the ileum (fig. 2b). Histological examination of biopsy specimens showed tumor cells resembling HCC on hematoxylin and eosin stain (fig. 2c). Immunohistochemical examination showed tumor cells positive for hepatocyte antigen (fig. 2d) and glypican-3 antigen (fig. 2e).

The tumor was diagnosed as a small bowel metastasis of moderately differentiated HCC. We decided to perform prophylactic endoscopic mucosal resection (EMR) to control the continuous bleeding after receiving informed consent from the patient and his family. During EMR, the non-lifting sign was positive after glycerol injection (fig. 3a) however, we then tried to resect the tumor (fig. 3b). Histological examination of the resected specimen showed tumor cells resembling HCC on hematoxylin and eosin stain (fig. 3c, d). The patient had no melena or anemia and was well after EMR (hemoglobin increased from 9.2 to $11.5 \mathrm{~g} / \mathrm{dl}$ ) without transfusion. However, he died of liver failure 2 months later.

\section{Discussion}

Metastasis to the gastrointestinal tract has been reported to involve direct invasion (82\%), hematogenous metastasis (9\%) and seeding (9\%); further, most cases have been found during autopsy [3]. This case was considered to be hematogenous metastasis because 
Igawa et al.: Small Bowel Metastasis of Hepatocellular Carcinoma Detected by Capsule Endoscopy

it involved multiple lung metastases, a portal vein tumor thrombus (VP2) and no peritoneal dissemination or direct invasion by CT. Endoscopic findings of gastrointestinal metastasis from HCC vary, but include raised and centrally ulcerated lesions, polypoid tumors and submucosal tumors [2, 4]. Several reported cases of small bowel metastasis have been diagnosed using CE and DBE [5-11]. However, only one case of small bowel metastasis from HCC diagnosed by DBE has been reported [5]. Honda et al. [12] reported that CT and fluoroscopic enteroclysis had significantly lower diagnostic yields of small bowel tumors $\leq 10$ $\mathrm{mm}$ in size, but CE and DBE had high yields of small bowel tumors regardless of size. In this case, the lesion was noted by CT, detected by CE and diagnosed by DBE. We suggest that CE should be the first line of small bowel scrutiny in patients with advanced cancer because it is less invasive. To date, the treatment for HCC with gastrointestinal tract metastases consists of planned symptomatic treatment and surgery. If a patient's general condition is good, multidisciplinary treatment including surgery should be considered. In this case, we performed EMR by DBE to control the continuous bleeding, since surgery was not indicated for this metastatic small bowel tumor because of the advanced HCC stage. The cause of anemia in patients with HCC has been determined to be associated with hypersplenism if hemorrhagic lesions have not been found in the upper and lower gastrointestinal endoscopy and there has been no small bowel scrutiny lately. In recent years, observation of the entire small bowel $[13,14]$ is possible using CE [15] and DBE [16]. We previously reported that small bowel lesions were significantly diagnosed by CE, especially for patients with ChildPugh class B disease or ascites or for patients with compensated liver cirrhosis and portal hypertension [17]. In this case, since the cause of anemia was bleeding from a small bowel metastasis, small bowel scrutiny for portal vein tumor thrombus and other organ metastases was performed.

In conclusion, we reported a case of small bowel metastasis of HCC detected by CE and resected by EMR to control continuous bleeding from the tumor. As in this case, there is a possibility of small bowel lesions as the cause of gastrointestinal bleeding and anemia in patients with liver cirrhosis and HCC. We suggest that CE should be actively performed in the search for small bowel lesions in those patients.

\section{Disclosure Statement}

The authors declare that they have no conflicts of interest concerning this paper.

\section{References}

1 The Liver Cancer Study Group of Japan: Primary liver cancer in Japan. Ann Surg 1990;211:277-287.

$\longrightarrow 2$ Chen LT, Chen CY, Liu GC, et al: Gastrointestinal tract involvement in hepatocellular carcinoma: clinical, radiological and endoscopic studies. Endoscopy 1990;22:118-123.

-3 Lin CP, Chen JS, Tseng HW, et al: Gastrointestinal metastasis in hepatocellular carcinoma: radiological and endoscopic studies of 11 cases. J Gastroenterol Hepatol 2000;15:536-541.

4 Sandler RS, Sartor RB, Bozymski EM: Endoscopic appearance of cancer metastatic to the stomach. J Clin Gastroenterol 1981;3(suppl 1):35-37.

5 Kunizaki M, Hidaka S, Isomoto H, et al: Diagnosis of small-bowel metastasis of hepatocellular carcinoma by double-balloon enteroscopy. Int J Surg Case Rep 2012;3:263-265.

6 Hayashi $\mathrm{H}$, Tani T, Tajima H, et al: Small intestinal metastasis from intrahepatic cholangiocarcinoma: report of a case. Surg Today 2011;41:859-864.

-7 Akamatsu H, Tsuya A, Kaira K, et al: Intestinal metastasis from non-small-cell lung cancer initially detected by ${ }^{18} \mathrm{~F}$-fluorodeoxyglucose positron emission tomography. Jpn J Radiol 2010;28:684-687. 


\section{Case Reports in
Gastroenterology}

\begin{tabular}{l|l}
\hline Case Rep Gastroenterol 2013;7:492-497 \\
\hline DOI: $10.1159 / 000357302$ & $\begin{array}{l}\text { @ } 2013 \text { S. Karger AG, Basel } \\
\text { www.karger.com/crg }\end{array}$ \\
\hline
\end{tabular}

Igawa et al:: Small Bowel Metastasis of Hepatocellular Carcinoma Detected by Capsule Endoscopy

8 Thoma MN, Saiyed SM, Charles RJ: Metastatic colorectal cancer to the small bowel - an uncommon cause of obscure GI bleeding: a three-case experience with review of the literature. J Gastrointest Cancer 2011;42:119-122.

-9 Vashi PG, Abboud E, Gupta D: Renal cell carcinoma with unusual metastasis to the small intestine manifesting as extensive polyposis: successful management with intraoperative therapeutic endoscopy. Case Rep Gastroenterol 2011;5:471-478.

$>10$ Kakugawa Y, Watanabe S, Kobayashi N, et al: Diagnosis of small-bowel metastasis of malignant pleural mesothelioma by capsule endoscopy and double balloon enteroscopy. Endoscopy 2007;39:E229-E230.

11 D'Amico FE, Ruffolo C, Romeo S, et al: Clear cell sarcoma of the ileum: report of a case and review of the literature. Int J Surg Pathol 2012;20:401-406.

12 Honda W, Ohmiya N, Hirooka Y, et al: Enteroscopic and radiologic diagnoses, treatment, and prognoses of small-bowel tumors. Gastrointest Endosc 2012;76:344-354.

13 Shishido T, Oka S, Tanaka S, et al: Diagnostic yield of capsule endoscopy versus double-balloon endoscopy for patients who have undergone total enteroscopy with obscure gastrointestinal bleeding. Hepatogastroenterology 2012;59:955-959.

14 Fukumoto A, Tanaka S, Shishido T, et al: Comparison of detectability of small-bowel lesions between capsule endoscopy and double-balloon endoscopy for patients with suspected small-bowel disease. Gastrointest Endosc 2009;69:857-865.

15 Iddan G, Meron G, Glukhovsky A, et al: Wireless capsule endoscopy. Nature 2000;405:417.

16 Yamamoto H, Sekine Y, Sato Y, et al: Total enteroscopy with a nonsurgical steerable double-balloon method. Gastrointest Endosc 2001;53:216-220.

17 Aoyama T, Oka S, Tanaka S, et al: Small bowel abnormalities in patients with compensated liver cirrhosis. Dig Dis Sci 2013;58:1390-1396.
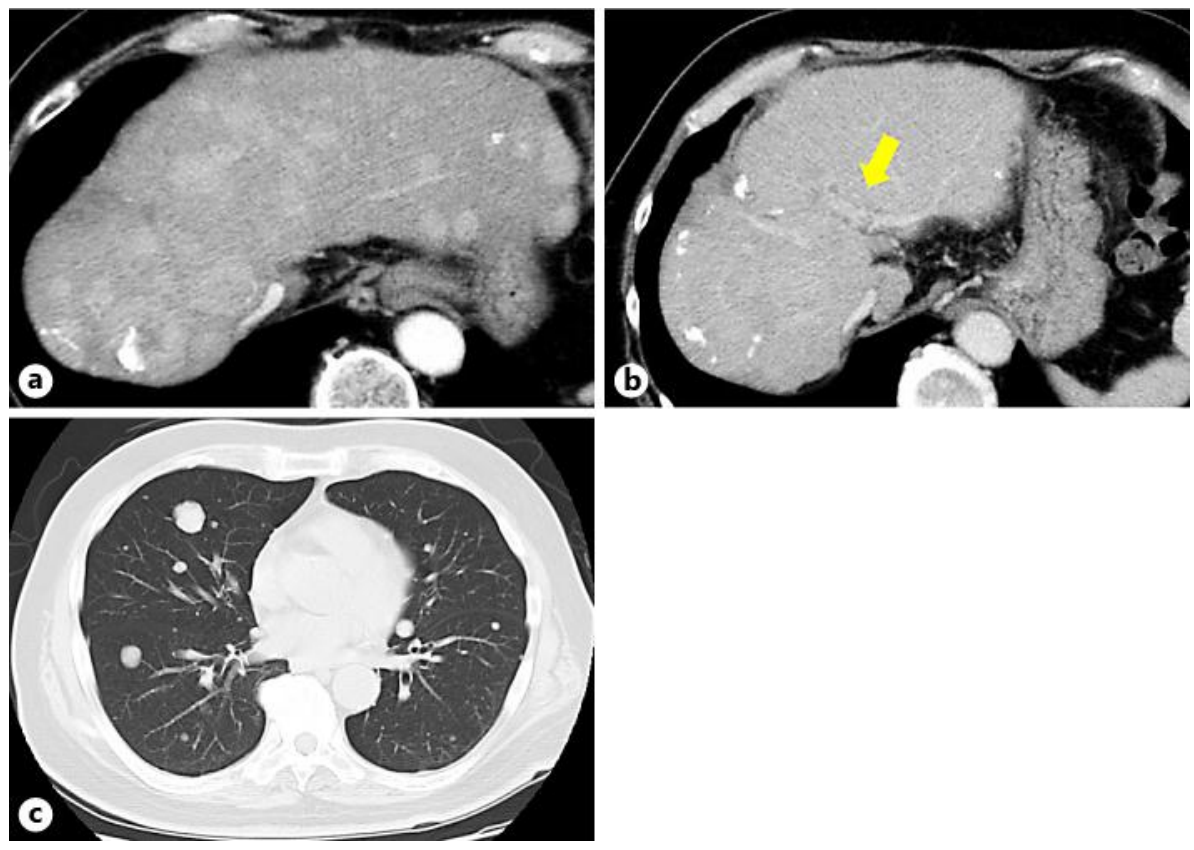

Fig. 1. a Abdominal CT showing multiple HCC in the liver. b Abdominal CT showing a portal vein tumor thrombus. c Chest CT showing multiple lung metastases. 


\begin{tabular}{ll|l} 
Case Reports in & \multicolumn{2}{l}{} \\
\cline { 2 - 3 } Gastroenterology & Case Rep Gastroenterol 2013;7:492-497 & $\begin{array}{l}\text { ○ 2013 S. Karger AG, Basel } \\
\text { www.karger.com/crg }\end{array}$ \\
\cline { 2 - 3 } & DOI: 10.1159/000357302 & $\begin{array}{l}\text { Igawa et al.: Small Bowel Metastasis of Hepatocellular Carcinoma Detected by Capsule } \\
\text { Endoscopy }\end{array}$
\end{tabular}
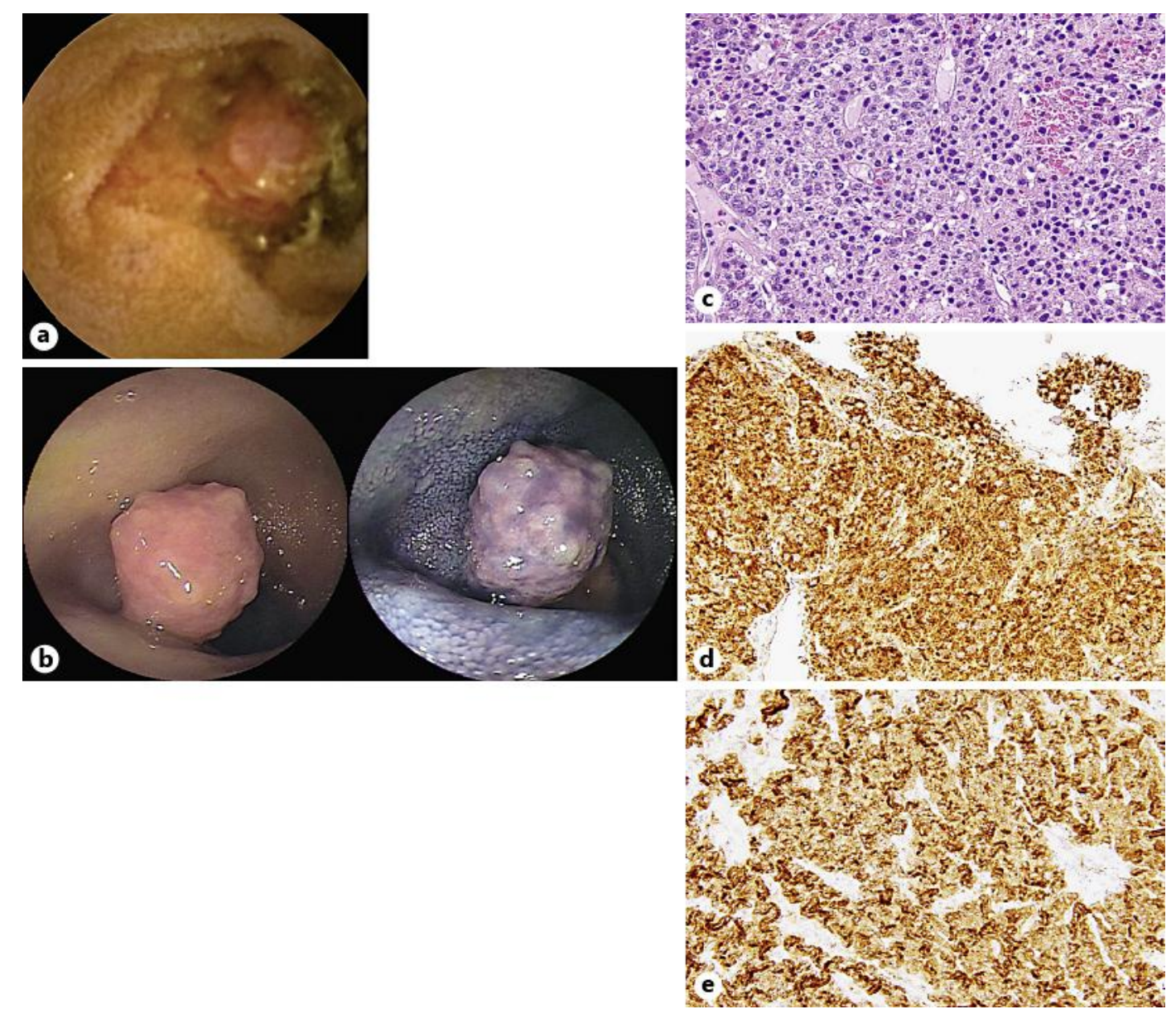

Fig. 2. a CE showing a polypoid lesion with bleeding in the ileum. b DBE showing a pedunculated polyp in the ileum. $c$ Histological examination of the biopsy specimens showing that the tumor cells resemble HCC on hematoxylin and eosin stain $(\times 400)$. d, e Immunohistochemical examination showing tumor cells positive for hepatocyte antigen (d) and glypican-3 antigen (e). 


\section{Case Reports in \\ Gastroenterology}

\begin{tabular}{l|l}
\hline Case Rep Gastroenterol 2013;7:492-497 \\
\hline DOI: 10.1159/000357302 & $\begin{array}{l}\text { ○ 2013 S. Karger AG, Basel } \\
\text { www.karger.com/crg }\end{array}$ \\
\hline
\end{tabular}

Igawa et al.: Small Bowel Metastasis of Hepatocellular Carcinoma Detected by Capsule Endoscopy
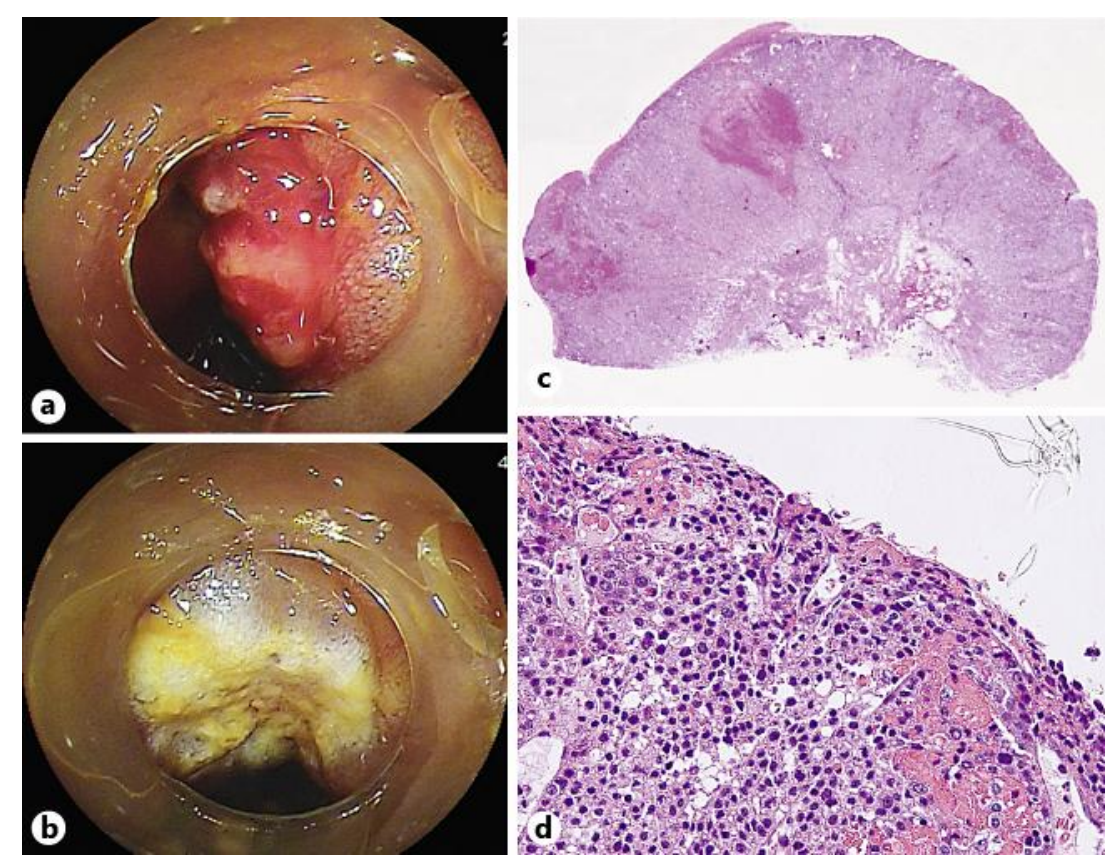

Fig. 3. a Positive non-lifting sign after glycerol injection. b Resected ulcer after EMR using DBE. c Crosssection with hematoxylin and eosin stain. d Histological examination of the resected specimen with hematoxylin and eosin stain $(\times 400)$. 